\title{
Innovation, Cross-Functional Team Effectiveness and Firm Performance: An Integrated Framework for Thai Automotive Industry
}

\author{
Sasiwimon Suebsook and Singha Chaveesuk
}

\begin{abstract}
With the need to develop a competitive position in current business environment, organizations need to realize the value of technology and innovation, which are widely recognized as one strategic tool for achieving sustainable competitive advantage. Innovation leads to product and process improvements, brings continuous developments that help firms survive, allow firms to grow more rapidly, be more efficient, and ultimately be more profitable. With the growing use of cross-functional teams in organizations and examination of an important role in the innovation process capacitate, knowledge sharing and resource capability. This paper sought to propose a model that was developed by integration of crossfunctional team contexts and innovation dimensions factors influencing firm performance. The research findings of this framework would be applied in the identification of factors influencing innovation and firm performance in the automotive industry of Thailand.
\end{abstract}

Index Terms-Innovation, cross-function teams, organization performance, automotive industry.

\section{INTRODUCTION}

The Automotive industry is a leading industry in generating country's gross domestic product (GDP) in Thailand, which makes significant contributions to the economy, employment, automotive technological developments in Thailand extending its support to supply chain and logistics related industries, which creates economic value for the country. With the need to develop a competitive position in today's global market, organizations need to realize the value of technology and innovation, which is widely recognized as one of the most important sources of sustainable competitive advantage [1].

Cross-functional teams (CFTs) are referred as working teams, which are comprised of group of people aimed towards to achieve common goals and objectives that require different functional expertise to work together [2]. Consequently, to perform the effective tasks, CFTs are necessary required to have the necessary support from organization to have the workforce organized in a structural manner to achieve firm's goals and objectives. All the members of CFTs have to plan and work together as a team, in order to achieve the goals and objectives stretching their limits. [3]. Endomonson and Nambhard illustrates that CFTs are composed of individuals with diverse functional skills,

Manuscript received July 24, 2019; revised October 15, 2019.

Sasiwimon Suebsook and Singha Chaveesuk are with Faculty of Administration and Management, King Mongkut's Institute of Technology Ladkrabang Bangkok, Thailand (e-mail: Sasiwimon_s@hotmail.com, singha@it.kmitl.ac.th). academic backgrounds, knowledge, disciplines, who are members of different functional departments, such as engineering, production or marketing, and who gather to solve a problem or perform a task to achieve the common goal [4]

According to Pimenta et al. [5], CFTs has become a useful strategic tool for organizations. The implication of team integration advocates resources utilization more effective in contrast to being managed by individual functional departments. According to the existing literature, this effectiveness refers to the ability to solve problems, produce quality goods and services and increase creativity and innovation [6].

The prominence of CFTs are increasingly emphasized in term of innovation [7]. Teams may facilitate knowledge integration and information exchange [8], possibly a working style of overcoming hierarchical to project accomplishment [9]. Notwithstanding, most study on CFTs have focused on the effectiveness of specific project teams, and the role of either team context, leadership or environmental factors [10]. There is not so much available literature, which has emphasized the strategic role and contribution of CFTs towards organization effectiveness and performance, especially the potential to generate complementary CFTs engagement in different activities for organization innovation.

\section{LITERATURE REVIEW}

\section{A. Cross-Functional Team Role in Auto Industry}

IATF stands for International Automotive Task Force, it is a group of automotive manufacturers, forms policies, rules, procedures and legislation with the aim to develop an international fundamental quality system requirements, primarily in participation of both products and services automotive suppliers. IATF members typically include the following vehicle manufacturers; BMW Group, Chrysler LLC, Daimler AG, Fiat Group Automobiles, Ford Motors, General Motors Corporation, PSA Peugeot-Citroen, Renault, Volkswagen AG, and the vehicle manufacturers' respective associations AIAG (US), ANFIA (Italy), FIEV (France), SMMT (UK) and VDA (Germany) [11]. From the product design point of view, understanding of customer requirements and leading product quality planning the APQP (Advanced Product Quality Planning) process has been mandatory for its implementation [12]. In order to implement the APQP according to IATF 16949, an organization requires the engagement of CFTs that includes related functions; marketing, product design, procurement, 
manufacturing, and distribution. The objective is to ensure a clear understanding of the voice of customer and to translate it into requirements, technical specifications, and special characteristics control [13].

\section{B. Cross-functional Teams}

Empirical researches on CFTs examine the useful points and contributions of CFTs to increase firms' performance in varied study areas. Denison, Heat and Khan developed and validated CFTs diagnostic model in their study, the results revealed that the influence of CFTs outcomes to organizational performance and goals [14]. Identical to the study of Pimenta et al. and Oliveira et al. [5], mentioned that the concept of the cross-functional integration has emerged from the need to facilitate the coordination between departments that is necessary to gain firms 'positive outcomes.

The implementation of CFTs increases the level of innovation and product development prosperity [15], [16]. These teams can have a long-term objective, to perform on permanent processes, although there may also be temporary project teams [17], [18]. Anthony et al. [19] indicated that CFTs, typically, capture the strength of several functional department in organization in performing their work. The research findings from these authors reveals the identical assertion of CFTs cooperation in working manner will ensure the generation, collection, dissemination, protection and disposition of the project information in a timely manner.

\section{Innovation and Firm Performance}

Innovation is construct derived from creativity as the basic element. The successful implementation of creative ideas within an organization can be in any dimension from notion of creative new products, process, or services within the organization's type of business [20].

Literature on innovation often mentioned that innovation is one of firms' key success factors and strengthens the competitive advantage. Regardless of the varied definitions for innovation, consensus on the definition of the innovation has not been defined [21]. German economist and political scientist, Schumpeter, who is the first person, defined the description of innovation as 'the driving force for development'. Five magnitudes of innovation including, products, processes, markets, new raw-material sources and new forms of organizations [22].

There are literatures in organizational development areas complied on CFTs' practice to improve as well as initiate the innovativeness, for instance, implementation of CFTs as part of the restructuring project within pharmaceutical firms. CFTs pursued the goals, expediting all relevant working processes, especially development timing, sustaining or improving innovative abilities and gathering the R\&D team allocation from difference location around the globe [18]. Zeller and other authors also contends on the emphasis of CFTs in developing strong interconnectedness between discovery, development and marketing activities and exploiting potential complementarities [23]-[26].

\section{Resources and Capabilities}

The theory of resources and capabilities aims to study on the foundation of values wherein the internal features of the firms generate economic profits, therefore internal resources and capabilities are the drivers to construct competitive advantage in order to achieve the firm's performance target. Resource capabilities are collected and used as a tool for business to compete more efficiently in markets. This approach considers that profitable firms are those that in some way better treat and retaining their resources and capabilities better than the competitors [27]-[29].

Firms' resources and capabilities are the main determinants of firms' performance [30] and they are important in providing and sustaining their competitive advantage [31]. From a performance point of view J. D. E. O. Cabral et al. reviewed several studies and summarized that firms typically develop and apply knowledge and skills that make them more innovative and increase their overall performance [32].

\section{E. Knowledge Sharing}

Organizational knowledge sharing is a type of work activities that gives an opportunity to businesses to increase organization's capabilities in order to serve their requirements and generate positive results and efficiencies that support maintaining a competitive advantage [33]. Knowledge sharing can also be defined as a social interaction process, requiring the integration of employee knowledge, expertise and skills in the entire of organization. For example can be a pool consists of sets of shared knowledge and information that can be kept and available for related employee to access to relevant information and learn to apply using knowledge networks within organizations [34]. Furthermore, knowledge sharing happens through both personal and organizational levels. For individual, knowledge sharing frequently happens when person talking to colleagues, discussing to get works done better, faster or finding alternative work solutions, for organization, knowledge sharing are groups of activity containing capturing, organizing, reusing, and transferring experience-based knowledge that animates within the organization. It is mandatory to grant that knowledge to be made available and accessible. There are numerous studies available which demonstrates that knowledge sharing is an important part of organization context; it enables organizations to enhance innovation performance and reduce redundant learning efforts [35], [36].

\section{CONCEPTUAL FRAMEWORK AND HYPOTHESIS DEVELOPMENT}

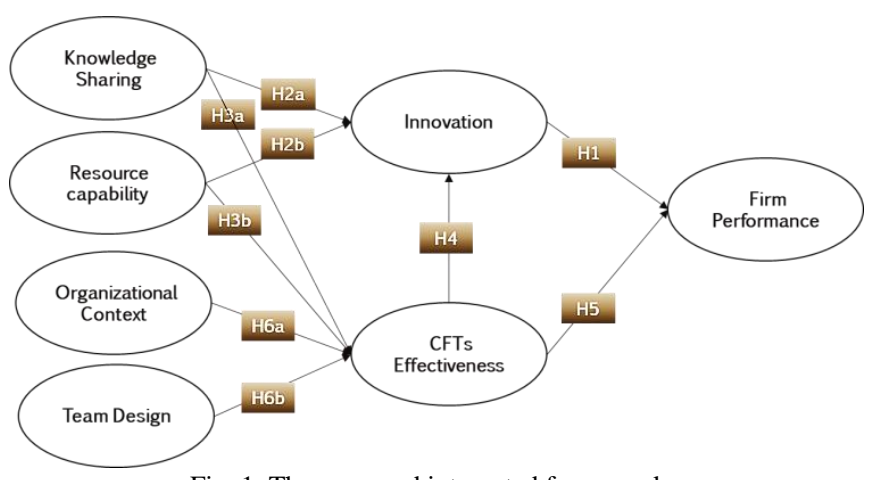

Fig. 1. The proposed integrated framework. 
Fig. 1 illustrates the three main constructs of the proposed framework, innovation, CFTs effectiveness and Firm Performance as well as its components. Each construct has been discussed hereunder, according to the studied literatures. These constructs were selected according to their capacity to describe the respective influencing to the automotive firms performance.

H1: Firm's innovation positively influence firm's performance

The first link in the proposed model is between innovation and firm performance. Most of the research regarding organization innovation are on innovation diffusion, which focus on how creative ideas spread to people [37]. Some other scholars mentioned that innovation is another essential key value for firms to outlast in a mutable business circumstance [38]. Establishing this link is supported by existing studies discovered that innovation is a key source of an organization's competitive advantage and lead to firms' profit [39]. Calantone et al. (2002) developed a framework for studying the influencing level of learning orientation, firm innovativeness to the firm performance in the U.S. manufacturing and service business. The paper revealed that firm innovativeness is positively influencing firm performance [35]. Therrien et al. (2011) studied the impact of whether innovation on firm performance in specific service firms. The outcomes indicate that, to increase sales revenue from innovations, firms need to be the pioneer in the market and introduce newness either products or services with high levels of creativity [40].

H2a: Knowledge Sharing positively influences firm's innovation

The first component of innovation construct is knowledge sharing. Hansen [41] presented that knowledge accumulation is a key criteria of organization successfulness, especially for firms involving in innovation. The initiation of new ideas and knowledge collaboration within organization assist improvement of firm products. Therefore, better learning capability, could expand innovation performance [42]. H F. Lin studied the influence of knowledge sharing to innovation capability in Taiwan. The result examined that knowledge sharing is positively related to firm innovation capability [43].

H2b: Resource and Capability positively influences firms' innovation

The second component of innovation construct is resource and capability within organizations. The relativity between innovation and performance is probably contrast [44]. Nevertheless, several studies indicated firms that performs well typically have easier access to capital to finance further investments and innovations [45], [46].

There are several methods to measure the level of firm's innovation, for instance, the investment allocated in innovation projects, employees dedicated towards innovation activities or team nomination to innovation assignment, number of newness introduced to the market or frequency of creative change in production process.

Henceforth, the spending of financial resources and the outcomes of innovative activities and projects will stipulate the direction of innovation in an organization [47]. Innovation advancements may result in multiple stages of evolution of products and processes, deriving for this result requiring a complete set of resources to become an innovative firm [48]. J. D. E. O. Cabral et al. examined the study of capability and innovation in export firm in Brazil indicated that resource capability is positively related to product innovation.

H3a: Knowledge Sharing positively influences Crossfunctional Team Effectiveness [32].

CFTs require proficiently trained through knowledge allocation and education involvement prior to assign and perform the taskforce effectively. For CFTs to be successful, member must share their knowledge and skills to contribute across an organization to produce better outputs within the time constraint [49]. Knowledge occurs in many facets, individual and team, [50]. An individual's technic can be transferred to group's knowledge or absorptive group knowledge can turn into individual's competency and lead to further improvement and hence to superior performance [51]. Castka et al. found in their study regarding factors affecting successful implementation of high performance teams in engineering of organization in UK that knowledge sharing is one of the factors affecting high performance team [52].

H3b: Resource and Capability positively influences Cross-functional Team Effectiveness

Firms that generating positive profit typically have sufficient financial resources to invest in innovation [53], [54]. The availability of complementary resources such as skilled labour and learning-by-doing effects may occur [55], [35]. Denison, Heat and Khan have studied the CFTs diagnostic model, the result mentioned that functions resources availability is affecting CFTs work performance [14]. Same as the findings by Holland, Gaston and Gomes revealed through the integrated diagnostic model examined that organization resources are one of critical success factors for cross-functional new product development team [56].

H4: Cross-functional team effectiveness positively influences firm's innovation

Empirical studies testifies the positive results also exist for the impact of CFTs effectiveness, to firm's innovation. Nevertheless, according to the introduction of CFTs to increase firms' innovation degree, Cooper and Kleinschmidt [57] examine the effectiveness of CFTs as one of firms' key success factors and provide the sample case of new product development team, while Gupta and Wilemon [58] emphasize the essential compliance to the development of CFTs by R\&D and technology managers. Stipp identified that innovation may occurred through contribution of CFTs in an organization of the public sector in Brazil [59].

H5: Cross-functional team effectiveness positively influences firm's performance

The cross-functional team's effectiveness related with work results of team whether they had perform well in order to meet organization's goals, such as targeted financial result, higher customer satisfaction score, better quality of products and meeting project timing plan [3]. CFTs provide an organization with some significant advantages: reduction of time for product development, reduction of development cost and proficient engineering change management [60]. As companies focused on achieving high quality of product innovation and improved customer satisfaction, team performance becomes critical to realize the above- 
mentioned objectives [61]. A number of studies have considered the use of CFTs in the innovation process and their effects on innovation outputs [16]. Oliveira et al. has indicated in the study of integration through CFTs in telecommunication company, the result presented that overall CFTs effectiveness positively related to firm's outcomes [18].

H6a: Organizational Context positively influence Crossfunctional Team effectiveness

H6b: Team Design positively influence Cross-functional Team effectiveness

To specify the CFTs effectiveness dimension, the normative model of team effectiveness for this study is was proposed by Salas, Dickinson, Converse, and Tannenbaum [61] which based on an adaptation of Hackman's (1983) model. The model suggested that two main dimensions for a team to be successful are organizational context and group design. Similar to the study of S. Holland, K. Gaston, and J. Gomes, the proposed model includes the organization context and group composition [56]. With the linkage mentioned, hypotheses are developed as above.

\section{CONCLUSION}

It is important to understand the firm's performance influencing factors, Innovation and CFTs were proposed within the context of the automotive industry of Thailand as two important drivers. Thus, Firms should focus on the development/ improvement plan to have in place in order to have effective CFTs, which would also be recognized as strategic innovation tool to make strategic business decisions accordingly.

\section{CONTRIBUtion}

The contribution of this research study is to identify, the factors influencing firm innovation and firm's performance, secondly the contribution of cross-functional teams to the innovation. The paper would highlights the aspects of the automotive industry of Thailand and the research findings will provide in-depth information to varied levels of management in organizations from front line managers up to top management levels such as general managers or managing directors to make strategic decisions for achieving sustainable competitive advantage and drive out its competitors.

\section{CONFLICT OF INTEREST}

The authors declare no conflict of interest.

\section{AUTHOR CONTRIBUTIONS}

Sasiwimon S. conducted the research; Singha C. Review and analyzed the data; all authors had approved the final version.

\section{REFERENCES}

[1] K. B. Kahn and J. T. Mentzer, "Logistic and interdepartmental integration," International Journal of Physical Distribution and Logistics Management, vol. 26, no. 8, pp. 6-14, 1996.

[2] J. R. Katzenbach and D. K. Smith, The Discipline of Teams, Harvard Business Review, 1993.
[3] D. G. Ancona and D. F. Caldwell, "Bridging the boundary: External activity and performance in organizational teams," Administrative Science Quarterly, vol. 37, pp. 634-665, 1992.

[4] A. C. Edmonson and I. M. Nambhard, "Product development and learning in project teams: The challenges are the benefits," The Journal of Product Innovation Management, vol. 26, pp. 123-138, 2009.

[5] M. L. Pimenta, A. L. Silva, and W. L. Tate, "Developing and managing cross-functional teams: A multi-case study of Brazilian manufacturing companies," Journal of Technology Management and Innovation, vol. 9, no. 2, pp. 1-16, 2014.

[6] M. B. Pinto, J. K. Pinto, and J. E. Prescott, "Antecedents and consequences of project team cross-functional cooperation," Management Science, vol. 39, no. 10, pp. 1281-1297, 1993.

[7] N. Rosenberg, Inside the Black Box: Technology and Economics, Cambridge University Press, 1982.

[8] G. Grabher, "The project ecology of advertising: Task, talents and teams," Regional Stud, vol. 36, no. 3, pp. 245-262, 2001.

[9] C. Zeller, "Project teams as means of restructuring research and development in the pharmaceutical industry," Regional Studies, vol. 36, pp. 275-289, 2002.

[10] B. Stamm, Managing Innovation, Design and Creativity, London: John Wiley and Sons, 2003.

[11] F Franceschini, M Galetto, D. A. Maisano, and L Mastrogiacomo, "ISO/TS 16949: Analysis of the diffusion and current trends," Journal of Engineering Manufacturer, vol. 225, no. 5, p. 735, 2011.

[12] J. Gruszka and A. Misztal, "The new IATF 16949: 2016 standard in the automotive supply chain," Research in Logistics and Production, vol. 7, no. 4, pp. 311-318, 2017.

[13] S. Stojanovic. (2017). Establishing advanced product quality planning (APQP) in IATF 16949. 16949 Academy. [Online]. Available: https://advisera.com/16949academy/blog/2017/09/13/establishingadvanced-product-quality-planning-apqp-in-iatf-16949/

[14] D. R. Denison, S. L. Heart, and J. A. Khan, "From chimney to crossfunctional teams: Development and validating a diagnostic model," Academy of Management Journal, vol. 39, no. 4, pp. 1005-1023, 1996.

[15] M. A. A. M. Leenders and B. Wierenga, "The effectiveness of different mechanisms for integrating marketing and R\&D," Journal of Product Innovation Management, vol. 19, no. 4, pp. 305-317, 2002.

[16] D. Jugend and S. L. Silva, "Management and innovation integration in new product development: Case study in a large Brazilian hightechnology company," Journal of Technology Management and Innovation, vol. 7, no. 1, pp. 52-63, 2012.

[17] A. C. Edmondson and I. M. Nembhard, "Product development and learning in project teams: The challenges are the benefits," Journal of Product Innovation Management, vol. 26, no. 2, pp. 123-138, 2009.

[18] E. A. Oliveira, M. L. Pimenta, P. Hilletofth, and D. Eriksson, "Integration through cross-functional teams in a service company," European Business Review, vol. 28, no. 4, pp. 405-430, 2016.

[19] E. L. Anthony, S. G. Green, and S. A. McComb, "Crossing functions above the cross-functional project team: The value of lateral coordination among functional department heads," Journal of Engineering and Technology Management, vol. 31, pp. 141-158, 2013.

[20] T. M. Amabile, "A model of creativity and innovation in organizations," Research in Organizational Behavior, vol. 10, pp. 123-167, 1998.

[21] M. Atalay, N. Anafarta, and F. Sarvan, "The relationship between innovation and firm performance: An empirical evidence from Turkish automotive supplier industry," Procedia Social and Behavioral Sciences, vol. 75, pp. 226-235, 2013.

[22] V. Vyas, "Innovation and new product development by SMEs: An investigation of scottish food and drinks industry," Edinburgh Napier University PhD Thesis, 2013.

[23] C. Zeller, "Project teams as means of restructuring research and development in the pharmaceutical industry," Regional Studies Association, vol. 36, pp. 275-289, 2002.

[24] D. Bonnett, "Nature of the $\mathrm{R} \& \mathrm{D} /$ marketing co-operation in the design of technologically advanced new industrial products," $R \& D$ Management, vol. 6, pp. 117-126, 1986.

[25] A. K. Gupta and D. Wilemon, "Changing patterns in industrial R\&D management," Journal of Product Innovation Management, vol. 13, pp. 497-511, 1996

[26] W. E. Souder and R. K. Moenaert, "Integrating marketing and R\&D project personnel within innovation projects: An information uncertainty model," Journal of Management Studies, vol. 29, pp. 485502,1992 .

[27] J. Barney, "Firm resources and sustained competitive advantage," Journal of Management, vol. 17, no. 1, pp. 99-120, 1991. 
[28] D. J. Collis and C. A. Montgomery, "Competing on resources: Strategy in the 1990s," Harvard Business Review, vol. 73, pp. 118$128,1995$.

[29] R. M. Grant, "The resourced-based theory of competitive advantage: Implications for strategy formulation," California Management Review, vol. 33, no. 3, pp. 114-135, 1991.

[30] G. A. Knight, S. T. Cavusgil, and S. T. Innovation, "Organizational capabilities, and the born-global firm," Journal of International Business Studies, vol. 35, pp. 124-141, 2004.

[31] J. C. Guan and N. Ma, "Innovative capability and export performance of Chinese firms" Technovation, vol. 23, pp. 737-747, 2003

[32] J. D. E. O. Cabral, A. F. M. Coelho, F. J. F. Coelho, and M. D. P. Costa, "Capabilities, innovation and overall performance in Brazillian export firms," RAM. Revista de Administração Mackenzie, vol. 16, no. 3, pp. 76-108, 2015.

[33] F. Reid, "Creating a knowledge sharing culture among diverse business units," Employment Relations Today, vol. 30, no. 3, pp. $43-$ 49, 2003.

[34] M. Hogel, K. P. Parboteeah, and C. L. Munson, "Team-level antecedents of individuals' knowledge networks," Decision Sciences, vol. 34, no. 4, pp. 741-770, 2003.

[35] R. J. Calantone, S. T. Cavusgil, and Y. Zhao, "Learning orientation, firm innovation capability and firm performance," Industrial Marketing Management, vol. 31, no. 6, pp. 515-524, 2002.

[36] H. Scarbrough, "Knowledge management, HRM and innovation process," International Journal of Manpower, vol. 24, no. 5, pp. 501516,2003

[37] E. M. Rogers, Diffusion of Innovations, New York: Free Press, 1995.

[38] J. D. Johnson, M. E. Meyer, J. M. Berkowitz, C. T. Ethington, and V. D. Miller, "Testing two contrasting structural models of innovativeness in a contractual network," Hum Commun Res., vol. 24 no. 2, pp. 320-348, 1997.

[39] S. Bharadwaj, P. R. Varadarajan, and J. Fahy, "Sustainable competitive advantage in service industries: A conceptual model and research propositions," Journal of Marketing, vol. 57, no. 4, pp. 83-99, 1993.

[40] P. Therrien, D. Doloreux, and T. Chamberlin, "Innovation novelty and (commercial) performance in the service sector: A Canadian firm level analysis," Technovation, vol. 31, pp. 655-665, 2001.

[41] M. T. Hansen, "The search-transfer problem: The role of weak ties in sharing knowledge across organization subunits," Administrative Science Quarterly, vol. 44, no. 1, pp. 82-111, 1999.

[42] A. Jantunen, "Knowledge-processing capabilities and innovative performance: An empirical study," European Journal of Innovation Management, vol. 8, no. 3, pp. 336-349, 2005.

[43] H. F. Lin, "Knowledge sharing and firm innovation capability: An empirical study," International Journal of Manpower, vol. 28, no. 3/4, pp. 315-332, 2007.

[44] P. Koellinger, The relationship between technology, innovation, and firm performance: Empirical evidence on e-business in Europe," Research Policy, vol. 37, no. 8, pp. 1317-1328, 2008.

[45] A. Abel and O. Blanchard, "The present value of profits and cyclical movements in investment, economic," Harvard Institute of Economic Research, Discussion Paper, pp. 249-273, 1983.

[46] R. Hubbard and A. Kashyap, "Internal net worth and the investment process: An application to U.S. agriculture," Journal of Political Economy, vol. 100, no. 3, pp. 506-534, 1992.

[47] J. Covin and D. Slevin, "Strategic management of small firms in hostile and benign environments," Strategic Management Journal, vol. 10, no. 1, pp. 75-87, 1989.
[48] D. J. Teece, G. Pisano, and A. Shuen, "Dynamic capabilities and strategic management," Strategic Management Journal, vol. 18, no. 7 , pp. 509-533, 1997.

[49] M. Mohamed, M. Stankosky, and A. Murray, "Applying knowledge management principle to enhance cross-functional teams performance," Journal of Knowledge Management, vol. 8, no. 3, pp. 127-142, 2004.

[50] N. M. Dixon, Common Knowledge: How Companies Thrive by Sharing What They Know, Boston: Harvard Business School Press, 2000, pp. 25-27.

[51] J. C. Spender, "Making knowledge the basis of a dynamic theory of the firm," Strategic Management Journal, vol. 17, pp. 45-62, 1996.

[52] P. Castka, C. F. Bamber, F. M. Sharp, and P. Belohoubek, "Factors affecting successful implementation of high performance team," Team Performance Management: An International Journal, vol. 7, no. 7/8, pp. 123-134, 2001.

[53] D. Acemoglu, "Technical change, inequality and the labor market," Journal of Economic Literature, vol. 40, no. 1, pp. 7-72, 2002.

[54] L. Hitt and E. Brynjolfsson, "Productivity, business profitability, and consumer surplus: Three different measures of information technology value," Management Information Systems Quarterly, vol. 20, no. 2, pp. 121-142, 1996.

[55] K. Arrow, "The economic implications of learning by doing," Review of Economic Studies, vol. 29, no. 3, pp. 155-173, 1962.

[56] S. Holland, K. Gaston, and J. Gomes, "Critical success factors for cross-functional teamwork in new product development," International Journal of Management Reviews, vol. 2, no. 3, pp. 231259, 2000 .

[57] R. G. Cooper and E. J. Kleinschmidt, "Benchmarking for firm's critical success factors in new product development," Journal of Product Innovation Management, vol. 12, pp. 374-391, 1995.

[58] A. K. Gupta and D. Wilemon, "Changing patterns in Industrial R\&D Management," Journal of Product Innovation Management, vol. 13 pp. 497-511, 1996.

[59] V. Kumar, K. A. Fantazy, U. Kumar, and T. A. Boyle, "Implementation and management framework for supply chain flexibility," Journal of Enterprise Information Management, vol. 19, no. 3, pp. 303-319, 2006.

[60] R. D. Banker, J. M. Field, R. G. Schroeder, and K. K. Sintia, "Impact of work team on manufacturing performance: A longitudinal field study," Academy of Management, vol. 39, no. 4, pp. 867-890, 1996.

[61] E. Salas, T. L. Dickinson, S. A. Converse, and S. I. Tannenbaum, "Toward an understanding of team performance and training," in Teams: Their Training and Performance, R. W. Swezey and E. Salas, Eds. Westport, CT, US: Ablex Publishing, 1992, pp. 3-29.

Copyright (C) 2020 by the authors. This is an open access article distributed under the Creative Commons Attribution License which permits unrestricted use, distribution, and reproduction in any medium, provided the original work is properly cited (CC BY 4.0).

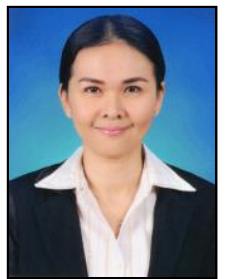

Sasiwimon Suebsook was born in Pung-nga, Thailand on August 16, 1978, graduated with bachelor's degree of business administration and master's degree of Industrial Administration and development.

She worked in automotive industry for more than 15 years and currently managing her own business and pursuing $\mathrm{Ph} . \mathrm{D}$. 